\begin{tabular}{|c|c|c|}
\hline & International Journal of Engineering \& Technology, $7(2)(2018) 784-794$ & \\
\hline & International Journal of Engineering \& Technology & \\
\hline SPC & $\begin{array}{c}\text { Website: www.sciencepubco.com/index.php/IJET } \\
\text { doi: } 10.14419 / \text { ijet.v7i2.12421 } \\
\text { Research paper }\end{array}$ & 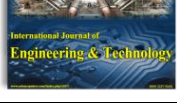 \\
\hline
\end{tabular}

\title{
Lightning strokes and its effects on historical monuments, heritage properties and important landmarks a detailed perspective of traditional and scientific methods of lightning protection systems
}

\author{
Srisailam Sreedhar ${ }^{1}$, Venkatesh Srinivasan ${ }^{2} *$ \\ ${ }^{1}$ Research Scholar, Vellore Institute of Technology, Vellore \\ ${ }^{2}$ Associate Professor, Vellore Institute of Technology, Vellore \\ *Corresponding author E-mail:venkatsri73in@gmail.com
}

\begin{abstract}
Lightning is one of the inevitable disastrous natural phenomena which present serious threat to tall structures including ancient monuments and electrical systems. Though researchers have carried out a wide gamut of research studies to analyze the extent of damage due to direct lightning strikes on important buildings and structures, the focus of this research is on understanding the effects of lightning on tall structures of historical importance and landmark monuments of significance. In this context, different types of Lightning Protection Systems (LPS) are being used to protect tall structures from lightning flashes. However, several complexities related to the appropriate choice of LPS continue to confront researchers since characteristics of lightning such as stroke current, striking distance, return stroke modelling, geometry of the structure etc. pose considerable challenges. This research study presents a detailed chronological overview of lightning strikes on ancient structures, cause and effects, review on LPS strategies along with its impacts on tall structures, historical monuments and landmarks. In addition, a detailed analysis based on a specific case study of a typical historical monument is carried out to ascertain the critical significance of the stipulated zone of protection essential for historical monuments and various risks involved during implementation.
\end{abstract}

Keywords:Electro-Geometric Method (EGM); Fixed Angle Method (FAM); Lightning Protection Systems (LPS); Rolling Sphere Method (RSM); Modified Rolling Sphere Method (MRSM).

\section{Introduction}

Lightning, a natural phenomenon, is a transient high current discharge natural phenomenon which occurs between clouds (intracloud) and cloud-ground [1]. Such discharges can be mainly categorized into two types namely cloud-to-cloud flashes (CC) and cloud-to-ground flashes (CG), of which the latter may have severe deleterious effects on humans and living animals, causing grievous injuries and sometimes death in addition to resulting into significant damage on human-made edifices and other important objects on earth. During CG flashes, a rumbling sound is generated along the length of the lightning channel as the atmosphere is heated by the electrical discharge [2]. The detrimental effects of lightning strokes on a wide variety of materials used in building structures, edifices and monuments like concrete, stone, wood, steel etc., may vary ranging from melting due to hotspot formation on metal to total disintegration of the granular internal structure of cement, concrete, wood etc. Such lightning strikes on buildings cause cracks on walls and beams which reduces the mechanical strength of the structure. These strikes may create consequently induced cascaded effects such as damage to idols, deterioration of heritage properties, defacement of rare sculptures, disfigurement of murals on walls etc., thus leading to irrecoverable damage to a wealth of cultural and heritage structures which need to be preserved for posterity.
Incidents of lightning on structures of importance and significance hence need to be deliberated from the context of a few major aspects such as probability of strikes, geographical location and geometry of structure etc. Depending on such significant features and further due to the need for clear understanding of types of lightning strokes (CG discharges) and relevant lightning model representation for tall structures, it is imperative that thorough understanding of lightning leader progression is established. It is interesting to note from another perspective that usually tall structures are more vulnerable to lightning [3] because of increased electric field due to reduction in breakdown potential between cloud and ground. It has been observed based on several studies by researchers [4] that tall towers, buildings and monuments worldwide are more susceptible to lightning strikes.It is evident that such lightning strikes on tall structures will create a path for the current to flow to the ground lest might cause malfunctioning of electric equipments installed inside the building, notwithstanding possible damages to the structure.

Recently several research studies [5] - [11] have reported direct lightning strikes on a few significant monuments and landmarks of importance worldwide including world heritage monuments such as Minaret at Putrajaya- Malaysia, Qutub Minar- India, Christ the Redeemer- Brazil, Falkirk church- Paris, Angel Moroni- Bern temple statue- Switzerland, Kanishka stupa- Pakistan, Sacred Achy Kaunakakai temple- Sri Lanka etc. 
It is hence evident from such studies that a credible Lightning Protection System (LPS) is essential to alleviate dangerous effects of such strikes and to minimize the irretrievable damages that may be created due to large lightning strikes. This research survey aims at providing an insight into various scientifically well-established LPS that may be utilized to prevent direct lightning strikes on heritage monuments, landmarks and The United Nations Educational, Science and Cultural Organization (UNESCO) properties.

\section{Major incidents of lightning strokes on his- torical ancient monuments - a generic chronological study}

There have been claims that several attempts to understand lightning were made even from the pre-historical days to rationally explain this natural phenomenon. Possible claims on understanding were made by Lacerates in $1 \mathrm{BC}$, as suggesting lightning was caused by collisions of clouds while Descartes attributed the cause for thunder due to the vibration of air in a huge organ pipe that is developed between two clouds [1]. Though scientifically unclaimed, possibly confirmed historical reports have indicated major lightning strikes on a few major and famous significant monuments and landmarks such as Colosseum - Italy on three different occasions [12] namely $217 \mathrm{AD}, 250 \mathrm{AD}$ and $320 \mathrm{AD}$, O' Rourke's
Tower- Ireland in 1135 etc., detailed research studies indicate that a possible major incidence of lightning strikes on historical monument of significance in the Indian peninsula was reported in [6] 1368 at Qutub Minar - India. A few other similar studies include significant lightning strikes reported at Parthenon Temple-Greece in 1656, Soho Square - Sussex in 1780 etc.

Incidentally, during 1752 Benjamin Franklin's experiment on lightning lead to the first scientifically accepted discovery of lightning and the fact that lightning comprises electric matter [1]. During his experiments, Franklin observed similarities in sparks and lightning and their characteristics such as crackling noise, chaotic path for progress etc. His experiments of flying a kite during a rainy day made of silk hand-kerchief which in turn was tied at the bottom of the thread holding the tied kite with a key and a small silk ribbon, lead to observing a spark that developed from the key. This has provided the scientific community with the first insight into understanding and documenting lightning as a phenomenon.

In this context, Table 1 summarizes a few recently reported lightning strikes on monuments and the extent of damage on the monuments during the past decade which in turn facilitates a clear understanding on the detrimental effects of lightning on historical monuments and landmarks of significance.

Table 1: Incidents of Lightning Damage on Important Monuments and Buildings

\begin{tabular}{|c|c|c|c|}
\hline Name of the monument & Location & $\begin{array}{l}\text { Year of lightning } \\
\text { stroke }\end{array}$ & Damage to the monument \\
\hline Parthenin Temple & Athens, Greece & June 2010 & Impairments to structures \\
\hline Statue of Liberty & New York, US & October 2010 & Hit by hundreds of strikes since 1886 \\
\hline Rajarajan Thiruvayil & Thanjavur, India & November 2010 & $\begin{array}{l}\text { Kalash (sacred vessel) on gopuram (tower) top } \\
\text { broken }\end{array}$ \\
\hline Pratapur Temple & Kathmandu Valley, Nepal & February 2011 & $\begin{array}{l}\text { Stairway to south side entrance debilitated } \\
\text { with one sculpture dislocated }\end{array}$ \\
\hline Eiffel Tower & Paris, France & July 2012 & No major damage reported \\
\hline Sigiriya Rock Fortress & Dambulla, Sri Lanka & October 2012 & One of Lion's paws at entrance damaged \\
\hline St. Peter's Dome & Vatican City, Holy See & February 2013 & No major damage reported \\
\hline World Trade Centre & New York, US & September 2013 & No major damage reported \\
\hline Sri Meenakshi Amman Temple & Meenakshi, India & December 2013 & East Raja-gopuram damaged \\
\hline Tower Bridge & London & January 2014 & Train services suspended \\
\hline Christ- The Redeemer Statue & Rio de Janerio, Brazil & January 2014 & Middle finger of right hand has got chipped \\
\hline Sydney Opera House & Sydney, Australia & April 2014 & Defaced with fine cracks \\
\hline $\mathrm{CN}$ tower & Canada & June 2015 & No major damage reported \\
\hline Golden Gate Bridge & California, US & $\begin{array}{l}\text { November } \\
2015\end{array}$ & $\begin{array}{l}\text { No damage to the structure but reported severe } \\
\text { power-cut in adjoining areas }\end{array}$ \\
\hline $\begin{array}{l}\text { Angel Moroni Statue- Bountiful Utah } \\
\text { Temple }\end{array}$ & USA & May 2016 & Damage to the head and back of statue \\
\hline Jameshwar Temple & Bhubaneshwar, India & July 2016 & Deep crack developed in walls \\
\hline Jameshwar Temple & Bhubaneshwar, India & July 2016 & Deep crack developed in walls \\
\hline The Washington Monument & Washington D.C., US & July 2016 & $\begin{array}{l}\text { Aluminium pyramidion melted due to repeated } \\
\text { strikes }\end{array}$ \\
\hline
\end{tabular}

Table 2: Landmarks with High Lightning Flashes

\begin{tabular}{lll} 
& \multicolumn{1}{c}{ Table 2: Landmarks with High Lightning Flashes } \\
\hline Name & Country & Lightning flashes per square kilometre per year \\
\hline Lake Maracaibo & Venezuela & 232.52 \\
Kabare & Democratic Republic of Congo & 205.31 \\
Kampene & Democratic Republic of Congo & 176.71 \\
Caceres & Colombia & 172.29 \\
Kifuka & Democratic Republic of Congo & 158 \\
Daggar & Pakistan & 143.11 \\
El Tarra & Colombia & 138.61 \\
Nguti & Cameroon & 129.58 \\
Butembo & Democratic Republic of Congo & 129.50 \\
Boende & Democratic Republic of Congo & 127.52 \\
\hline
\end{tabular}

In addition, from the viewpoint of major landmarks worldwide, details of most frequent lightning strikes as reported by The $\mathrm{Na}-$ tional Astronauts and Space Administration (NASA) and leading news corporations are compiled and deliberated in Table 2.

It is evident from the detailed summary of the damages to significant monuments and edifices of structural importance that it can be observed that the monuments hit by lightning on several significant and probable events culminates into irrevocable damage which requires extensive plan for meaningful protection and maintenance. This is obvious since replicating the monuments and materials which were utilized by ancestors may not be exactly created with the present modern construction techniques and tools. It is apparent that there is an urgent need for systematic and scientific approach to develop reliable LPS for historical/archaeological monuments of importance. Archaeologists have also expressed their concern over the inadequate protection measures in the most historical monuments. 


\section{Lightning strokes - types, return stroke models and methods for protection}

\subsection{Types of lightning flashes}

Research studies indicate that lightning flashes have been categorized into several major categories namely: 1. cloud to ground (CG) lightning usually characterized by either a downward nega- tive ground flash or a positive ground flash; 2. Upward ground flash (GC) classified either as upward positive ground flash or upward negative flash; 3 . cloud-to-cloud (CC) lightning involving intra-cloud flashes and air discharges. In addition, research studies also indicate other forms of lightning which may include Anvil Crawlers, Bead Lightning, Ribbon Lightning, Ball Lightning, Sprites, Blue Jets, Elves etc. Table 3 gives a recap of the various types of lightning strikes and its unique characteristics.

Table 3: Lightning Flashes Types, Properties \& Characteristics [13] - [15]

\begin{tabular}{|c|c|c|}
\hline Type of Lightning Flash & Properties & Characteristics \\
\hline Intra-cloud flashes & $\begin{array}{l}\text { Lightning inside a single cloud jumping from one } \\
\text { charge region to oppositely charged region of the } \\
\text { cloud }\end{array}$ & $\begin{array}{l}\text { Actual channel may be obscured inside the cloud which may } \\
\text { be visible to the observer }\end{array}$ \\
\hline $\begin{array}{l}\text { Downward positive ground flash } \\
(+\mathrm{CG})\end{array}$ & $\begin{array}{l}\text { Discharge between cloud and ground by a down- } \\
\text { ward positively charged stepped leader; } \\
\text { Less in common. }\end{array}$ & $\begin{array}{l}\text { Identified by distinctive lack of branching; Consists of one } \\
\text { return stroke which is very bright and intense; Sounds like a } \\
\text { series of deep, low frequency sonic booms }\end{array}$ \\
\hline Anvil Crawlers (Bolt from Blue) & $\begin{array}{l}\text { Horizontally crawling tree like intra-cloud dis- } \\
\text { charges }\end{array}$ & $\begin{array}{l}\text { Very high-altitude events; Soft rolling thunder due to dis- } \\
\text { tance from the observer; Occurs independently within cloud } \\
\text { or based on type of CG discharge }\end{array}$ \\
\hline Anvil Lightning & $\begin{array}{l}\text { CG discharge in highest cumulonimbus cloud re- } \\
\text { gions, travelling horizontally long distance from the } \\
\text { thunderstorm before descent to earth }\end{array}$ & $\begin{array}{l}\text { Occur at locations with clear Blue skies; Travels over dis- } \\
\text { tance more than ten miles. }\end{array}$ \\
\hline Ribbon lightning & $\begin{array}{l}\text { Caused by wind blowing lightning channel side- } \\
\text { ways during exposure }\end{array}$ & $\begin{array}{l}\text { Stronger the wind and closer the lightning strike, more is the } \\
\text { horizontal displacement with a broadened appearance }\end{array}$ \\
\hline Ball Lightning & $\begin{array}{l}\text { An illuminated sphere that occurs during thunder- } \\
\text { storms }\end{array}$ & $\begin{array}{l}\text { May move fast, slow or stay stationary; Can be quiet or pro- } \\
\text { duce a hissing sound, crackling noise or loud bang; May last } \\
\text { for seconds to minutes; Disappear slowly or suddenly }\end{array}$ \\
\hline Sprites & $\begin{array}{l}\text { Large but weak luminous flashes appearing above } \\
\text { an active thunderstorm with positive CG lightning } \\
\text { strokes }\end{array}$ & $\begin{array}{l}\text { Sprites structure varies from single to multiple vertically } \\
\text { elongated spots and bright group extending from cloud top to } \\
\text { altitudes up to } 60 \text { miles. }\end{array}$ \\
\hline Blue Jets & $\begin{array}{l}\text { High altitude optical ejections from the top of the } \\
\text { electrically active regions of thunderstorms }\end{array}$ & $\begin{array}{l}\text { Propagate upward in narrow cones }\left(15^{\circ}\right) \text {, fanning out and } \\
\text { disappearing at heights of about } 40-50 \mathrm{~km} \text { with a lifetime of } \\
\text { tenths of a second }\end{array}$ \\
\hline Elves & $\begin{array}{l}\text { Rapidly expanding disc-shaped regions of luminosi- } \\
\text { ty, lasting less than a thousandth of a second; Oc- } \\
\text { curs above energetic }+\mathrm{CG} \text { or }-\mathrm{CG} \text { in ionosphere }\end{array}$ & $\begin{array}{l}\text { Caused due to the electromagnetic pulse from a thunderstorm } \\
\text { propagates in to the ionosphere. }\end{array}$ \\
\hline
\end{tabular}

\subsection{Lightning return stroke models - a generic perspec- tive}

Several researchers have postulated lightning models [16] related to cloud charge formation and separation based on electrostatic physics and numerical computation strategies. Since the focus of this research study is more on the lightning strokes and its corresponding models, the aspects related to charge formation and separation modeling are not taken up for deliberation. In this context, lightning stroke models from the perspective of return stroke has become the most important aspect for lightning studies since its characterization and quantification at various distances in relationship to the struck object provides researchers with inputs on induced voltages and currents. In addition, the focus of such models is on development of return stroke representation that can replicate and emulate the electromagnetic fields and corresponding parameters of lightning. Further, these models also provide avenues to evaluate the risk levels presented by lightning which in turn would yield credible statistical distribution estimates of peak currents and its corresponding derivatives during lightning flashes.

Lightning hazards are basically due to the return stroke established during the descending of lightning leader on to the earth or a grounding electrode [17]. Such strokes may either travel along with the leader channel or might take different paths to neutralize and redistribute the accumulated charges during the formation of main stepped leader [17]. Since, it is obvious from these aspects that there exist substantial complexities in measuring the current parameters of direct lightning channel, the research community is faced with challenges pertaining to development of accurate and credible return-stroke models. Over the past few decades, return stroke models have been developed which can be classified into [18] - [20] four major categories namely Gas Dynamic Model (Physics Model), Electromagnetic Model, Distributed Circuit Model (Transmission Line Model) and Engineering Model.

\subsubsection{Gas dynamic models or physics models}

These models [21] utilize fundamental physics related conservation laws such as conservation of energy, conservation of charge and conservation of momentum etc., in combination with mathematical modeling aspects related to fluid dynamics and thermodynamics to evaluate and obtain temporal and radial variation of lightning channel temperature, pressure, radius, acoustic parameters, optical radiation, electrical properties such as electron density and conductivity etc.

\subsubsection{Electromagnetic models}

Such models consider [22] lightning as a vertical conducting wire with a finite radius over a plane. The mathematical formulation involves utilizing Maxwell's equation and either current or voltage at the ground-end as the boundary condition. Numerical evaluation techniques such as Method of Moments, Finite Difference Method (FDM), Finite Element Method (FEM), Charge Simulation Method (CSM), Boundary Element Method (BEM) etc., may be formulated and utilized to obtain the distribution of current along wire. 


\subsubsection{Distributed circuits models}

These models assume that the return-stroke channel is a vertical transmission line [23] with specific values of inductance (L), capacitance $(\mathrm{C})$ and resistance $(\mathrm{R})$ per unit length. Such models are further sub-divided into two categories wherein the first type considers the return stroke as an injection of current from the ground end located over a plane while the second methodology considers representing the leader channel as a charged vertical transmission line. In the former model, the solution is obtained in terms of temporal variation of current as a function of time and height along the transmission line. The latter considers the leader channel as a charged vertical transmission line, wherein the return-stroke is represented by connecting the charged transmission line to the ground. It is pertinent to note that upon solving the transmission line equations, the temporal and spatial variation of the current can be obtained.

\subsubsection{Engineering models}

Models of this category [24] are obtained by utilizing the strengths of the three previously described models were in the experimental data forming a successful and simplest return-stroke model is realized. These models are further divided in to three types: current-generation models, current-propagation models and currentdissipation models.

Table 4 provides a succinct comparison of the various models from the perspective of its unique representation and characteristic features

Table 4:Comparison between Return Stroke Models [25]

\begin{tabular}{lll}
\multicolumn{3}{c}{ Table 4:Comparison between Return Stroke Models [25] } \\
\hline $\begin{array}{l}\text { Gas Dynamic Model } \\
\text { Electro-magnetic Mod- } \\
\text { els }\end{array}$ & $\begin{array}{l}\text { Distributed Circuit } \\
\text { Model }\end{array}$ \\
\hline $\begin{array}{l}\text { monservation - mass, } \\
\text { energy }\end{array}$ & $\begin{array}{l}\text { Based on Maxwell's } \\
\text { Equation }\end{array}$ & $\begin{array}{l}\text { Based on transmis- } \\
\text { sion line model }\end{array}$ \\
$\begin{array}{l}\text { Related to radial } \\
\text { segment of lightning } \\
\text { channel and its } \\
\text { shock wave }\end{array}$ & $\begin{array}{l}\text { Concerned with the } \\
\text { lossy antenna approxi- } \\
\text { mation to the lightning } \\
\text { channel }\end{array}$ & $\begin{array}{l}\text { Approximation for } \\
\text { electromagnetic mod- } \\
\text { els }\end{array}$ \\
$\begin{array}{l}\text { Outputs of the model } \\
\text { are temperature, } \\
\text { pressure and mass } \\
\text { density }\end{array}$ & $\begin{array}{l}\text { Model outputs are cur- } \\
\text { rent distribution along } \\
\text { the channel which intern } \\
\text { helps in finding remote } \\
\text { electric and magnetic } \\
\text { fields }\end{array}$ & $\begin{array}{l}\text { Represents the transi- } \\
\text { ent process on a verti- } \\
\text { cal transmission line }\end{array}$ \\
\hline
\end{tabular}

\subsection{LPS - traditional approaches}

It is pertinent to note from the context of LPS that lightning has significant impact on tall structures. Some of the major risks [26] of lightning related to structures and internal equipment are:

- Fire initiated due to lightning causing electrical arching of lightning current within structures

- Fire due to the heating of conductors or arcing due to melted conductors

- Punctures of structure roofing due to plasma heat at lightning point of strike

- Mechanical damage including dislodged materials at point of strike.

Research studies reveal that till very recently LPS for buildings including monuments and allied structures have been based on two broad and generic approaches namely traditional and scientific. In the context of this research study, traditional approaches imply utilizing techniques that are claimed to have been implemented by our ancestors across the globe during the construction of architectural marvels and edifices of extraordinary significance. From the perspective of scientific method it is implied utilizing techniques for lightning protection based on scientifically crossvalidated and well-established studies which necessitates lightning measurement [16] and analysis based on tools such as Klydono- graph (also called lightning/ strike counter), lightning alarm system, Boy's Camera for capturing lightning strokes, other modern techniques for lightning detection and measurement such as fiber optic sensor network, multi-sensor lightning location systems etc. Scientific approaches for LPS comprise Conventional and nonconventional techniques. Franklin rods and Faraday cages form a part of convention technique [27] while the non-conventional LPS is further classified into two categories namely Active Attraction LPS and Active Prevention/Elimination LPS. Detailed and thorough research studies and analysis of internationally proven lightning protection standards perused worldwide reveal that nonconventional systems are yet to provide scientifically wellestablished and experimentally validated results [28] - [30] to vindicate the claim made proponents of Early Streamer Emission (ESE) air terminal manufacturers on its ability to offer better zone of protection. Hence, the scope of this research study does not propose detailed deliberations on various methods postulated under the non-conventional methods of LPS.

\subsubsection{Temple architecture and allied structures}

As religious monuments worldwide, irrespective of the type, location, geography etc. are a part of extraordinary architectural splendor and carvings, these excellent structures necessitate elaborate and considerably secure LPS for its reliable existence and sustenance. In this context, traditional schemes which have been claimed to have been utilized in temples and related architectures having its wide presence in the Indian sub-continent have a wide range of protection methods to alleviate the monuments from lightning damages. In specific, towers in temples (Gopuram) acts as an attractor of lightning due to one or more mounted metallic structure of the form representing an inverted pot and a conic spire (Kalash), claimed to be spiritual source for receiving positive energy from the universe [31]. Kalash is made of an alloy of metals which could include gold, silver, brass, copper and lead, which acts as a plausible electro-magnetic receptor. Nine grains called familiarly in Hindu religious practices called 'Navadhanya'[32] which includes Barley, Ragi, Varagu (Kodo-Millet), Thinai, Kambu, Horse-gram, Saamai, Cholam, Paddy are filled inside the pot. Millet is used in huge quantities. Further, it is also claimed by experts in temple architecture and buildings (Stapathis) that Millet is used in large quantities as it seemingly conducts electromagnetic waves. A few other experts of spiritual and traditional temple architecture present the claim on utilizing Varagu since it is specifically though to be receptor of large lightning currents and hence dissipater of lightning energy. It is obvious during visits to several temple cities and towns specifically in Sothern India that the plan of the temple town invariably indicates positioning of gopurams as rectangular / square structured edifices in four directions of the town thus possibly offering zone of lightning protection under it thereby protecting both temples and areas around it. Further, it is also asserted by the spiritual community that performing the religious rites related to renovation of the Kalash called 'Kumbabhishek' is carried out periodically [32] (usually in cycles of 12 years) to ensure refilling of the grains and refurbishing the metal enclosure.

Incidentally, from the standpoint of lightning strikes in temples and monuments related to sculptures there have been reported incidents of lightning strikes during the recent past. Khajuraho Temple in Madhya Pradesh of India on June 2015 had suffred from damages to the stone building. After this incident, officials in Odissa acted to protect monuments in the state of Odisha from lightning and other hazards. Archaeological Survey of India (ASI)- Bhubaneswar-Orissa, in collaboration with industrial partners have recently embarked on renovation and refurbishment work on installing lightning protection system on several temples in the region including the largest $12^{\text {th }}$ century Jagannath Temple in Puri, one of the most famous temples in the world. The Meenakshi Sundareswarar Temple, another UNESCO monument under the aegis of ASI has been struck by lightning recently. Recent studies indicate that concerted efforts have been made to put 
a robust lightning protection system in place in this monument Five sophisticated lightning conductors are installed at the towers in the north, east, west, south and central area to protect the temple structure [33], with one conductor for each tower. Each lightning conductor has a protection zone of radius about 80 meters. The overall protection zone covered by the 5 lightning conductor's spreads across 17 acres.

\subsubsection{Stupa and pagoda architecture}

Research studies both historical as well as scientific indicate that several monuments in China and Sri Lanka are believed to be invulnerable to lightning for several hundreds of years. Studies [34] indicate that a wooden pagoda in Yingxain Shanxi built in 1056 $\mathrm{AD}$ and completed in $1195 \mathrm{AD}$ was found not struck by lightning or no damage is observed. Some researchers say that it was protected by considerably well-chosen property of insulation [35] which formed an inherent part of the structure. Pagodas have an iron prop in the middle of the steeple and all the ornaments on the steeple are constructed among the prop. Several iron chains are tied to edges of the roof to fix the steeple and extended to the ground, acts like conductors for the lightning to have a free flow path to discharge without damaging the pagoda. Similarly, the Buddhist temples have a pinnacle which attracts the lightning towards it. The current is distributed symmetrically along the surface of the temple [36] giving rise to low current density, resulting the potential gradient too be low along a line from the top surface to the bottom. Thus, side flashes at the bottom of the stupas are less probable and hence less vulnerable.

\subsubsection{Minaret architecture}

It is a tower from which the prayers are offered five times each day. These towers are always abutted or connected to a mosque with one or more open balconies. The call to offer prayers is made from the highest roof near the mosque. Incidentally, the oldest minaret claimed to be in North Africa at al-Qayrawan, Tunisia and which was built between 724 and $727 \mathrm{AD}$ [37], to the best of the knowledge of the authors, have not had reported lightning incidents on the structure. One of the minarets of Charminar-India was claimed to have got struck by lightning in 1670's and was reported to have been restored. The Great Mosque of AleppoSyria, the $11^{\text {th }}$ century minaret of Umayyad Mosque reportedly was virtually completely damaged due to the lightning strikes in 1481 and subsequently rebuilt. Further, a $13^{\text {th }}$ century Ince Minaret Medrese located in Konya-Turkey was struck by lightning in 1901 and partially damaged the structure. Husein-Dasa's mosque located at Pljevlja- Montenegro which includes a minaret added to its southern side was struck by lightning in 1911. It is obvious from most of such studies and observations that the minarets being naturally taller than mosques, when installed appropriately with lightning (air terminal) rods possibly also offers the requisite zone of protection and hence protects the adjoining mosques from lightning damage.

\subsubsection{Church architecture}

There are many reported incidents during the past several hundreds of years whereby churches have been found to have got damaged due to lightning strikes [38]. Martinikerk Church in Doesburg, Netherlands was struck by lightning in 1547 with both the structures of the church and the tower heavily damaged. St. Olav's Church considered to have been built in $12^{\text {th }}$ century was reported to have been struck in 1590 by severe lightning, possibly completely damaging the church. Historians also claim that Campanile of San Marco in Venice-Italy was struck by lightning and probably damaged and reworked nine times between 1388 and 1762. Nieuwe Kerk at Delft- Netherlands built in 1496 was struck by lightning and tower was observed to have got damaged twice in 1536 and 1872. Se Cathedral in Goa-India, built in 1640, was reported to have been struck by lightning which debilitated the left tower.

\subsection{LPS - Scientific approaches}

From the perspective of scientifically accepted and welldocumented approaches followed worldwide, the lightning protection ideology has been taken up for implementation from late $18^{\text {th }}$ century when Benjamin Franklin installed the first lightning rod [1]. It is interesting to note that the findings [39] and scientific philosophy of utilizing an air terminal (lightning rod) as postulated by Franklin in $1752[40,41]$ and subsequently installing the rod on his house had a coincidence in utilizing the same arrangement also on San Marco campanile in 1766 which possibly prevented lightning damages.

The conventional LPS consist of three basic parts [1] that provide low impedance metal path:

- An air- termination system on the roof or elevated locations

- A system of ground terminals (earthing conductor)

- A conductor (down-conductor) connecting the strike termination to the ground terminals

This simple mechanism of using a lightning rod [42] as an air termination device was popularly used for the first few decades without additional scientific analysis and studies such as computation of zone of protection, angle of protection, height of protection etc. Hence, initially the system was taken up for implementation based on the premise that such systems were most appropriate for tall structures and that tall air terminal provides a very good protection zone.

Various considerably validated methods have been proposed by the scientific community utilizing national and international standardization and professional bodies such as National Fire Protection Association (NFPA) [43], International Electrotechnical Commission (IEC) [44], Institute of Electrical and Electronics Engineers (IEEE) [45], British Standards (BS), Bureau of Indian Standards (BIS) [46] etc to obtain and ascertain the lightning protection zone for conventional methods. Fundamentally methods for lightning protection may be classified into two major categories namely geometric and electro-geometric. In the case of geometric method also called popularly as Fixed Angle Method (FAM), empirical and considerably several laboratory studies are utilized to obtain the protection based on only the geometric (dimensional) parameters of the structures taken up for lightning protection. The electro-geometric methods utilize both geometric parameters like apex protection angle $(\alpha)$, height of protection, area of protection etc as well as electrical parameters such as stroke current $\left(\mathrm{I}_{\mathrm{s}}\right)$, estimate of Critical Flash-Over (CFO), Ground Flash Density (GFD) etc. Examples of geometrical methods include use of method related to obtaining the lightning protection based on cone of protection, tent of protection, empirical curves etc. Examples of electro-geometric methods include (EGM), Rolling Sphere Method (RSM), Modified Rolling Sphere Method (MRSM) etc. Mesh method is also another unique protection technique wherein the object to be shielded from lightning is to be viewed from the context of protection of flat surfaces which forms a part of a much larger and a complex geometrical structure.

\subsubsection{Fixed angle method (FAM)}

The FAM is the oldest method to express the protection zone of the air terminations, where the protection angle $(\alpha)$ is given by the ratio of horizontal distance (r) to the height ( $h$ ) of the rod as depicted in Fig. 1.

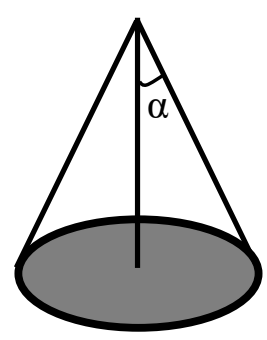

Fig. 1: FAM with Single Mast 
A two mast FAM of LPS is represented in Fig. 2, which covers an internal angle of $45^{\circ}$ and an external angle of $30^{\circ}$ covered under zone of protection according to IEEE-998 [45]. However, variants of the acceptable protection angle [46] are also in vogue which is much less conservative.

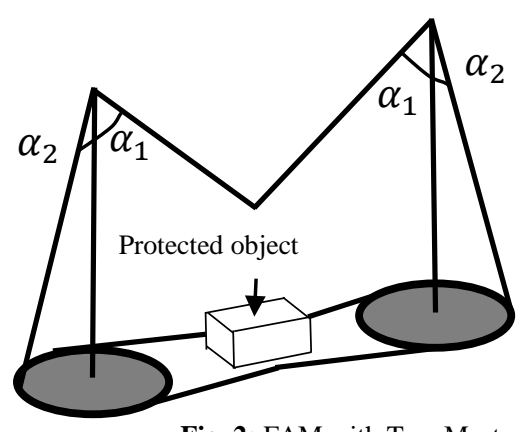

$\alpha_{1}=45^{\circ}$

$\alpha_{2}=30^{\circ}$

Fig. 2: FAM with Two Masts.

The fixed angle method values have been evolving for over 150 years and the change in the extremities of values of angle have varied from $7^{0}$ to $83^{0}$ [47], where no preferred method is being followed because of divergent lightning conditions. Several international standards like IEC, IEEE, NFPA etc. have resorted to a more conservative value of the protective angle considering this statistical variability in the lightning stroke current magnitudes as well as difficulties in replicating laboratory tests that attempt to emulate real-time lightning strokes. Further, these aspects are also possibly interrelated to the location (region) of such strikes and hence the iso-keraunic level, type of lightning stroke $(-\mathrm{CG},+\mathrm{CG})$, geographical properties, class of LPS etc., plays a vital role in obtaining a credible estimate/ index on the minimum value of protection angle.

FAM has been found to be most appropriate for high voltage transmission lines during several applications during the $20^{\text {th }}$ century. Such lines were typically about $10-15 \mathrm{~m}$ high and wherein studies based on reliability indicate that a maximum allowable protection angle of $30^{\circ}-45^{\circ}$ was observed to be most appropriate. With the progress in transmission technology, the height of the transmission lines reached $20 \mathrm{~m}-30 \mathrm{~m}$ by 1930 for a $100-\mathrm{kV}$ transmission system. However, studies taken up during the period suggested a decreased protection angle, in the range of $30^{\circ}-35^{\circ}$ till 1958. Later, studies indicated that several lightning strike shielding failures [48] in USA on UHV lines above $300 \mathrm{kV}$ were reported which made the issue evident that it would be impetrative to decrease the protection angle to be lesser than $20^{\circ}$. Such studies [47] clearly indicate and establish the hypothesis that as the height of transmission lines is increased the protection angle needs to be correspondingly lessened.

In this context it is pertinent to note that based on exhaustive studies and analysis, IEC 62305-3 has provided exhaustive details on the protection angle based on varying height of the object to be protected as an empirical curve plot. [44] also deliberates on this aspect based on studies wherein detailed analysis clearly indicate that variations in height of the protected object angle led to change in the protection angle ranging from $23^{0}$ to $70^{\circ}-79^{\circ}$ as a function of height above a reference plane. However, cross-validation on the efficacy of protection angle for values greater than $70^{\circ}$ has not been established and has left much to be desired. A comparison of the variations of protection angle for varying height of object based on IEC 62305-3 and [47] clearly indicates the details of the extent (range) of protection angle and cone of protection offered by benchmark height of objects. This aspect is compared and summarized in Table 5 and is depicted in Fig. 3 and Fig. 4.

Table 5: Protection Angle Values

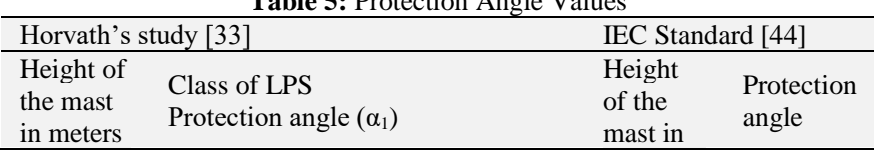

\begin{tabular}{lllllll}
\hline & & & & \multicolumn{3}{l}{ meters } \\
M & I & II & III & IV & M & $\alpha$ \\
60 & - & - & - & $23.23^{0}$ & 50 & $15^{0}$ \\
45 & - & - & $23.23^{0}$ & $33.78^{0}$ & 40 & $20^{0}$ \\
30 & - & $23.23^{0}$ & $37.45^{0}$ & $45.21^{0}$ & 25 & $30^{0}$ \\
20 & $23.23^{0}$ & $37.45^{0}$ & $47.98^{0}$ & $53.97^{0}$ & 10 & $45^{0}$ \\
\hline
\end{tabular}

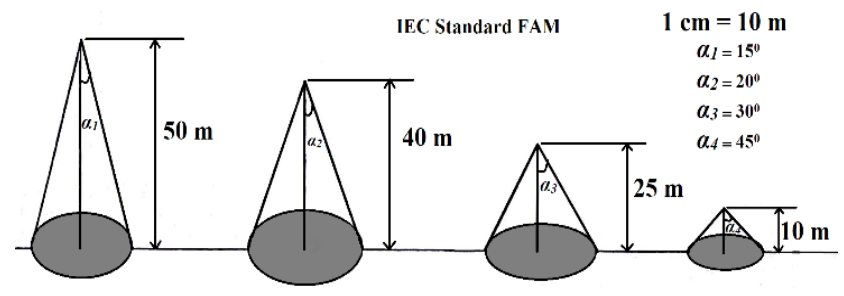

Fig. 3: FAM by IEC Standard

Horvath's FAM $\quad 1 \mathrm{~cm}=10 \mathrm{~m}$

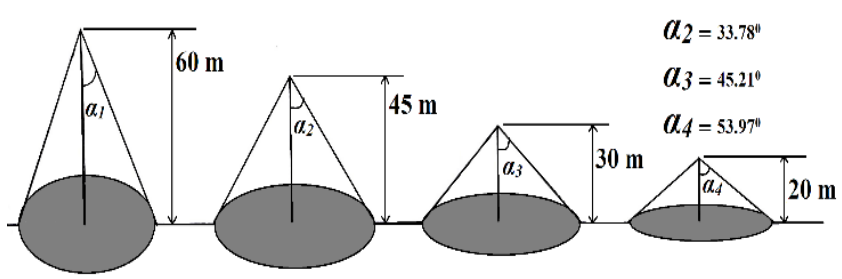

Fig. 4: FAM by Horvath.

Further, studies and analysis in [47] indicate that using the FAM based on IEC 62305-3 for installation of air terminals would lead to difficulties in realizing the effective protection for 3D structures. This is evident as reported in such studies [49] that this may be attributed to its inherent characteristic of fixing up of regular geometry and balanced area considered for protection zoning which is factually not the case in practice with tall structures. In this context, it is worth mentioning that RSM can be used to eliminate these issues caused by FAM.

\subsubsection{Rolling sphere method (RSM)}

This lightning protection method is based on EGM [1] which assumes that the point of lightning strike is obtained when the stepped leader approaches a critical distance to get attracted to the earth or a tall structure, called the 'striking distance'. This distance depends on the electric field generated by the stepped leader, which in turn is determined by the distribution of charge on the stepped leader channel [50]. In this method, an imaginary sphere of radius which encompasses the protected zone and which is equal to striking distance is construed to be rolled over and along the air terminals. In addition to this volume the volume/ area under the sphere is considered as lightning protection zone [51]. The RSM is one of the most effective and direct implementation of the EGM philosophy for 3D geometries [52] hence a natural and recommended technique as per IEC 62305-3. Subsequently, the method has also been incorporated into the Hungarian standards in 1962 and into the edition of the NFPA in 1980 and further adapted by several national standards worldwide

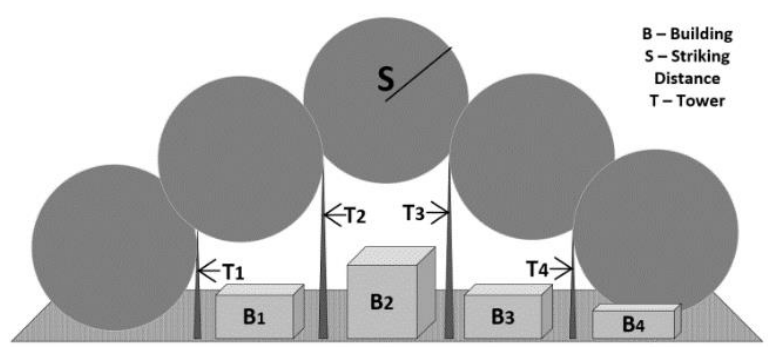

Fig. 5: Rolling Sphere Method of LPS. 
Fig. 5 depicting the area covered under the sphere indicates the lightning protected zone and the object $\mathrm{B}_{4}$ lies in the unprotected zone. It is pertinent to note that this depiction assumes that airterminal is not installed on the $\mathrm{B}_{4}$ building.

Detailed study indicates a plethora of research studies carried out by researchers worldwide utilizing the RSM to analyze and inves- tigate the protection zone volume by with appropriate assumptions Studies and analysis carried out by researchers [53], [54] with relevant assumptions and related lightning parameter estimation taken up during the course of such studies are deliberated in Table 6.

Table 6: Research and Development in the Protection Area for RSM

\begin{tabular}{|c|c|c|c|}
\hline Research authors & Year & Assumptions & Formula developed \\
\hline Golde & 1945 & $\begin{array}{l}\text { Line charge density }\left(\rho_{\mathrm{s}}\right) \text { on the vertical } \\
\text { stepped leader channel decreases expo- } \\
\text { nentially with increasing height above } \\
\text { ground }\end{array}$ & $\begin{array}{c}\rho_{\mathrm{s}}=\rho_{\mathrm{s} 0} \mathrm{e}^{-\mathrm{z} / \lambda} \\
\mathrm{Q}=\rho_{\mathrm{s} 0} \lambda\left[1-\mathrm{e}^{\wedge}(-\mathrm{H} / \lambda)\right] \\
\mathrm{I}_{\mathrm{pf}}=\mathrm{kQ}\end{array}$ \\
\hline Berger & 1963 & $\begin{array}{l}\text { Current waveforms of first return strokes } \\
\text { to measure on Monte San Salvatore was } \\
\text { utilized to obtain relationship between } \\
\text { first return stroke peak current } \mathrm{I}_{\mathrm{pf}} \text { and } \\
\text { charge ground within } 2 \mathrm{~ms} \text { from begin- } \\
\text { ning of return stroke }\end{array}$ & $\mathrm{I}_{\mathrm{pf}}=29.4 \mathrm{Q}^{0.7}$ \\
\hline Whitehead and Armstrong & 1968 & $\begin{array}{l}\text { Uses experimental results of switching } \\
\text { and lightning impulse discharge charac- } \\
\text { teristics of large air gaps }\end{array}$ & $r_{s}=6.7 \mathrm{I}_{0}^{0.8}$ \\
\hline Whitehead and Love & 1973 & $\begin{array}{l}\text { Based on observations of power supply } \\
\text { networks, critical lightning current that a } \\
\text { line can carry without damage is deter- } \\
\text { mined }\end{array}$ & $\mathrm{r}_{\mathrm{s}}=2 \mathrm{I}+30\left(1-\mathrm{e}^{\wedge}(\mathrm{I} / 6.25)\right)$ \\
\hline Gilman and Whitehead & 1977 & $\begin{array}{l}\text { The famous relationship currently used } \\
\text { by all international standards }\end{array}$ & $r_{s}=10 I^{0.65}$ \\
\hline Eriksson & 1987 & $\begin{array}{l}\text { Collection Volume Model to calculate } \\
\text { attractive radius for a vertical mast on the } \\
\text { flat ground to improve EGM }\end{array}$ & $r_{a}=0.84 I^{0.74} h^{0.6}$ \\
\hline Mousa and Srivastava & 1989 & $\begin{array}{l}\text { Relationship based on revised EGM } \\
\text { Downward stepped leader and upward }\end{array}$ & $\mathrm{r}_{\mathrm{s}}=8 \mathrm{kI}^{0.65}$ \\
\hline Dellera and Garbagnati & 1990-1997 & $\begin{array}{l}\text { leader moving towards each other and } \\
\text { forming a junction }\end{array}$ & - \\
\hline Petrov and Waters & $1995-2004$ & $\begin{array}{l}\text { The charge density of the negative } \\
\text { downward leader as } r_{\mathrm{s}}=0.43 \mathrm{I}^{2 / 3}\end{array}$ & $\begin{array}{l}\text { The negative flash striking distance } \mathrm{r}_{\mathrm{s}}(\mathrm{m}) \text { is given by } \\
\qquad \mathrm{r}_{\mathrm{s}}=0.8(\mathrm{I}(\mathrm{h}+15))^{2 / 3}\end{array}$ \\
\hline Becerra and Cooray & 2007-2008 & $\begin{array}{l}\text { Developed a self-consistent model for the } \\
\text { initiation of upward leader by using } \\
\text { electric field induced by the downward } \\
\text { leader }\end{array}$ & $r_{s}=1.9 I^{0.9}$ \\
\hline
\end{tabular}

Where $r_{s}$ is the striking distance in $\mathrm{m}$ and $\mathrm{I}$ is the lightning current in $\mathrm{kA}$.

It is obvious that the RSM which the most common method for external lightning protection is found suitable for constructing air termination systems for 3D structures [52] and most appropriately only if the radius (striking distance) is not exceeding $60 \mathrm{~m}$ [47]. Further, it is also evident from studies that the RSM is stipulated as a well-established technique in almost all the international and national standards due to its effective and reliable performance though surprisingly ease of application.

\subsubsection{Mesh method}

This method introduced by Maxwell in 1898, is considered possibly the best method to protect buildings from lightning by encasing or enclosing it in a Faraday cage [1]. It consists of installation of a meshed network on the top of the roof/ ceiling of the overall structure. This methodology is one of the most accepted and credible techniques especially for the protection of flat surfaces on a building [55]. The dimensions of the mesh network are determined according to the stipulations and guidelines laid down by IEC 62305. From a generic perspective, the dimensions of the mesh shall not be greater than the values specified in stipulations indicated in IEC 62305 [44].The values of currents flowing into the structure are the minimum downward leader current that may terminate on the structure with the size of the down-conductor used for lightning protection carefully designed based on varying levels/ class of lightning strikes [56]. Fig. 6 depicts a typical layout of mesh method for structures. It is worth noting that air terminals are installed at equal intervals which in turn are connected with mesh and grounded [57].

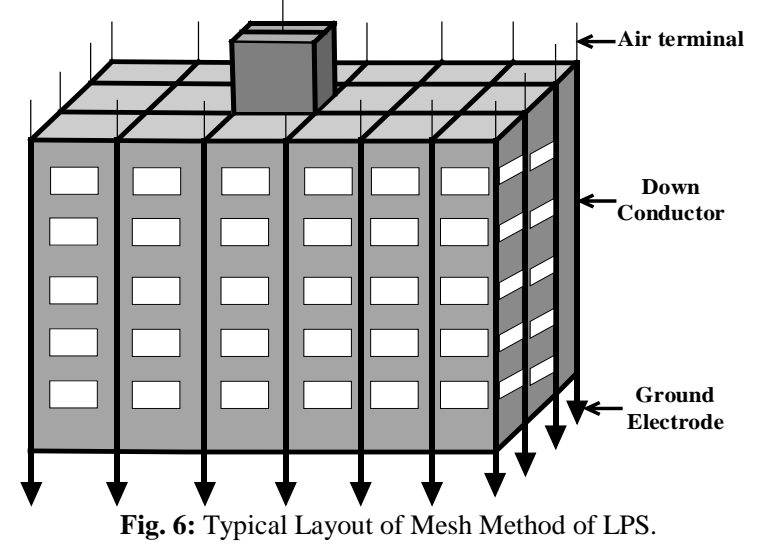

\subsubsection{Empirical curve method}

In 1941 Wagner, McCann and MacLane conducted tests on CG model by employing a positive impulse to a ground plane or a horizontal shield wire and a conductor located near the electrode. The space between the electrode, shield wire and conductor are varied with each simulated discharge and results had been plotted. A series of curves had been developed in relation to the height and spacing of shield wired and masts, which aided in giving more accurate design to determine the number, position and height of shielding wires and masts [45]. In empirical design, small failure percentage could be allowed to develop a method which provides shielding using statistical methods. In Mousa's EGM model, striking distance is reduced by $10 \%$ to eliminate strokes totally, to alleviate the damage in the protected area [58]. To have a valid 
statistical approach, the sample size needs be very large and necessitates meeting such criteria. Therefore, small samples like substations with less exposure area cannot be shielded by statistical approach. However, such structures can be shielded with small permitted failure rate [59]. Table 7 summarizes some of the major unique features and characteristics such as protection angle, geometry of structure, ease of use etc. of the various LPS methods.

Table 7: Comparison between LPS Methods

\begin{tabular}{lll}
\hline Fixed Angle Method & Rolling Sphere Method & Mesh Method \\
\hline $\begin{array}{l}\text { Based on only internal and } \\
\text { external angle }\end{array}$ & $\begin{array}{l}\text { - Based on surge impedance, allowable } \\
\text { strike current, Striking distance (radius } \\
\text { of sphere) }\end{array}$ & $\begin{array}{l}\text { - Based on the allowable current } \\
\text { through the conductors }\end{array}$ \\
$\begin{array}{l}\text { Suitable for simple-shaped } \\
\text { buildings }\end{array}$ & - Suitable for all the cases & $\begin{array}{l}\text { Empirical Curve Method } \\
\text { tory model tests (Wagner Model) }\end{array}$ \\
$\begin{array}{l}\text { Angle decides the protection } \\
\text { zone }\end{array}$ & $\begin{array}{l}\text { - Area covered under the sphere deter- } \\
\text { mines the protection zone }\end{array}$ & $\begin{array}{l}\text { - Plane under the mesh gives the } \\
\text { protection zone }\end{array}$ \\
$\begin{array}{l}\text { Easy to calculate and imple- } \\
\text { ment }\end{array}$ & $\begin{array}{l}\text { - Complexity increases with the shape of } \\
\text { structure to be protected }\end{array}$ & $\begin{array}{l}\text { - Complexity increases with the } \\
\text { shape of the structure to be } \\
\text { protected }\end{array}$ \\
$\begin{array}{l}\text { Less down conductors are } \\
\text { used }\end{array}$ & $\begin{array}{l}\text { - Moderate number of conductors are } \\
\text { of the structure increase }\end{array}$ & $\begin{array}{l}\text { - More down conductors are used } \\
\text { sion lines }\end{array}$ \\
\hline
\end{tabular}

\section{LPS for trees}

Similar to tall buildings and edifices of significance, trees are also equally vulnerable to lightning. Many trees are struck by lightning every year. The damage caused by lightning to trees may vary from being totally unharmed to that of complete destruction [60]. Most of the trees normally burnt when struck by lightning, rarely leave a trace of damage on the tree. This may be attributed to the fact that when lightning strikes, such discharges prefer the shortest path among the branches of the tree which comprises the leas impedance thus terminating to the ground. Species of trees [61] commonly struck by lightning include oak, elm, maple, poplar, ash, spruce, fir, pine and tulip-tree etc. As trees are sometimes taller than the adjacent objects like houses, buildings, poles etc., the streamer produced by the trees are invariably be much higher than that of other structures.

A tree LPS consists of a conducting cable at the highest point of the tree, specifically designed utilizing copper fasteners to fasten the cable to the entirety of the tree i.e., from the trunk to the ground $[43,60]$. The end of the cable is attached to a ground rod, which is buried deep down into the soil to avoid damage to the main roots of the tree. Trees with many branches would necessitate appropriate additional conductors along the branches which are interconnected to the main conductor along the trunk. This enables the discharge of lightning freely to ground when lightning strikes the branches. LPS deliberated and illustrated in detail in NFPA 78 is depicted in Fig. 7 as a generic layout.

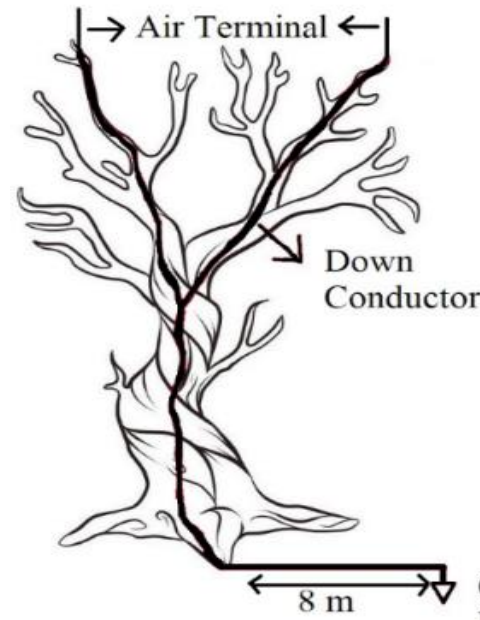

Ground

Fig. 7: Tree LPS

Electrode

In this context it is be pertinent to note that religious structures invariably comprise as a part of the monument worships and prayers also offered to trees which are considered by the belief systems practiced by religious groups. Such sacred trees are called 'sthalvriksha' and form a part of integral worship by devotees belonging to such groups.

Further, there have been reported incidents of damages to endangered species [61] of forests and fauna including rare trees which form a part of mangrove forests [62], [63]. It is interesting to note from such studies that gaps due to lightning strikes on mangrove trees lead to formation of a canopy [64] due to a group of trees which decay and cease to exist. The regeneration process [65] of such trees is also observed to be not most likely due to the substantial change in the soil cohesiveness [66], density [67] etc. Further, such studies also display the migratory tendencies of rare animal species which build burrows near such trees. Hence, it is evident that it is appropriate to devise appropriate techniques to prevent loss of natural treasures such as fauna and forests due to severe lightning strikes.

\section{Sample case of LPS for a typical tall mon- ument}

A hypothetical yet considerably realistic case study of lightning protection is taken up for analysis which is considered for a historical structure comprising surrounding area related to the monument premises with pre-installed lightning protection is considered for case study. Fig. 8 depicts the overall layout elevation drawing of the monument area with its tower structure and related premises. The drawing shows three tall towers wherein the middle tower is $100 \mathrm{~m}$ from and $200 \mathrm{~m}$ from the first and the third tower respectively. It is also envisaged as a part of the study that lightning is construed to have been struck at a vulnerable point i.e., more realistically the middle tower since presumably no air-terminal is installed atop the structure while the towers on its either ends are provided with LPS air terminals.

Scale: $1 \mathrm{~cm}=40 \mathrm{~m}$

1,2 \& $3=$ Tall towers

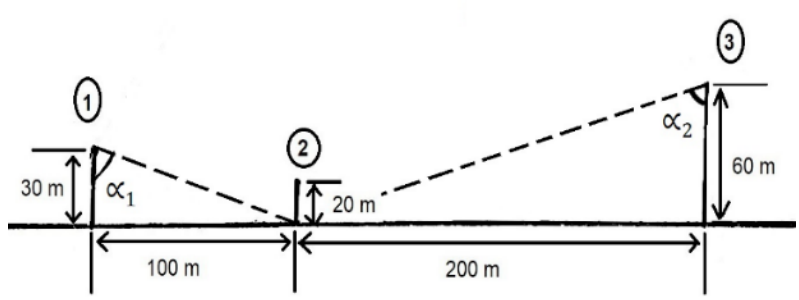

Fig. 8: FAM LPS Implementation. 


\subsection{Based on FAM - LPS method}

It is observed that acceptance norm as stipulated by Indian Standard (IS: 2309), IEEE998 and NFPA 780 are not adhered to and the protection offered to the middle tower is completely inadequate. It is evinced that the protection apex angles measured for first tower towards second (middle) tower is $\propto_{1}=70^{\circ}$ while that of the third tower to the middle tower is $\propto_{2}=72.5^{\circ}$. It is evident that the shielding effectiveness of the middle tower both at the base as well as the tower top is completely insufficient and inadequate to provide reliable and credible protection when struck by strokes. It is in fact obvious from the study that the bottom of the tower itself does not fall under the zone of protection (cone of protection) of the stipulated FAM LPS strategy though air terminals are installed at the first and third towers.

\subsection{Based on RSM - LPS method}

The equations used for calculations of RSM are: Collection area of a structure $\left(\mathrm{A}_{c}\right)$ is given by

$A_{c}=(L * W)+2\left(L * H_{1}\right)+2\left(W * H_{1}\right)+\left(\pi * H_{1}^{2}\right)$

Where, $\mathrm{L}=$ length of the structure in $\mathrm{m}$

$\mathrm{W}=$ Width of the structure in $\mathrm{m}$

$\mathrm{H}=$ Height of the structure in $\mathrm{m}$

Probability of striking distance $(\mathrm{P})$ of structure is given by,

$\mathrm{P}=\mathrm{A}_{\mathrm{c}} * \mathrm{~N}_{\mathrm{g}} * 10^{-6}$

Where, $\mathrm{N}_{\mathrm{g}}=3.7$ as per IS: 2309 value of lightning flashes per year per square $\mathrm{km}$

Acceptable range is $\left(\mathrm{P}_{0}\right)=10^{-5}$

Using the ratio of $\left(\mathrm{P} / \mathrm{P}_{0}\right)$, the value of stroke current $\left(\mathrm{I}_{\mathrm{s}}\right)$ is found from relevant standards that the value is $200 \mathrm{kA}$.

The striking distance from the value of stroke current is calculated using

$\mathrm{S}=10 * \mathrm{I}^{0.65}$

The equation used for plotting the zone of protection outside of the structure is

$A_{x}=\sqrt{S^{2}-\left(S-H_{x}\right)^{2}}$

Using the above equations, the zone of protection is drawn. Fig. 9 illustrates the protection zone provided by the air terminals using RSM. It is evident that the middle tower is not covered under the protected area even though air terminals are installed on the first and the third towers of the monument structures. The results indicate that both GM as well as EGM LPS techniques yielded similar inferences on the insufficiency of lightning shielding protection related to the middle tower and the prospective peril of the tower to be susceptible to lightning strikes.

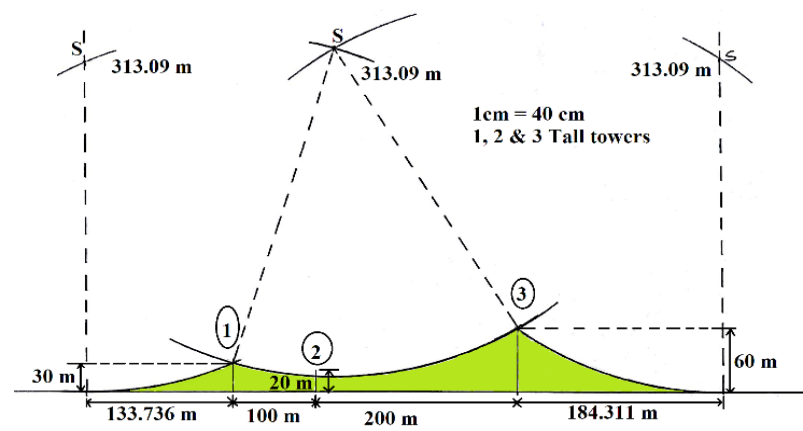

Fig. 9: RSM LPS Implementation.

\subsubsection{Revised rolling sphere method (RRSM)}

Incidentally, in recent times researchers have performed several laboratory experiments and also analyzed real-time situations where the structures with LPS has got struck by lightning based on which the formula for striking distance (S) has been revised as

$\mathrm{S}=8 * \mathrm{I}^{0.65}$

Using equation (5) the protection zone has been drawn as indicated in Fig. 10 and it has been clearly observed and established that the second tower (middle tower) is not covered under the safe zone of lightning protection.

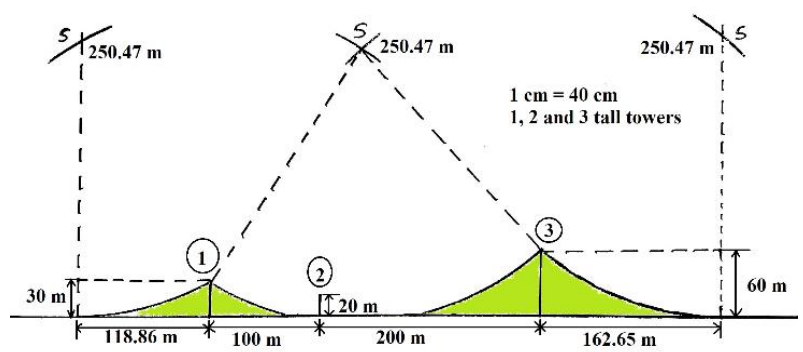

Fig. 10: RSM LPS Implementation.

Hence, it is evident from the case study taken up with all stipulated LPS methodologies that it is imperative that the middle tower should also necessarily requires installation of at least an air terminal to ensure a secure and reliable lightning protection zone in the vicinity of all the towers which forms a part of the monument's premises.

\section{Conclusion}

It is observed that, in recent years there have many reports on hazards caused by lightning, possible attributed to growing global warming phenomenon and consequent climate change which in turn has led to irreplaceable damage to properties of historical relevance and significance in addition to perils related to human livelihood. Some of the significant aspects of lightning strikes on monuments and its impacts are summarized as follows:

1) Ancient buildings and monuments are built for remembrance of history and culture. Damage done to some monuments cannot be recovered as those ancient constructional techniques are uniquely different from that of modern ones.

2) Many of the historical structures are tall in structure, which makes them vulnerable to the lightning; hence, necessitate exhaustive and proven methods for protection and conservation.

3) In addition to protection of heritage monuments and important structures, it is evident from studies that it is equally exigent to protect rare trees, fauna and historical forests from getting damaged in large by lightning as these may rapidly become an extinct species in nature's creation.

4) In spite of exhaustive procedures and different lightning protection methods there have been continuing incidents and reports of lightning strikes on the protected areas of monuments which have caused severe damage. It is evident from such studies that detailed and more exhaustive analysis will be necessary on the veracity of such schemes during design and implementation. Some of the possible pitfalls during implementation may include inaccurate modeling representation, incorrect execution of the design details during execution at the site of construction, lack of thorough understanding of safety and grounding arrangements etc.

5) Considering the huge onus on scientific community in conserving monuments, architectures and landmarks of significance it is most appropriate that considerable efforts are focused on possibly evolving a standardized guideline, more 
so, specifically in the domain of protection of heritage structures since it is evident that the trade-off of conflicting requirements of spiritualistic and scientific mindset continue to baffle and confront the society.

\section{Acknowledgement}

The corresponding author of this research work is grateful to the Department of Science \& Technology (DST) - Government of India for sanctioning and funding the Bilateral India-Sri Lanka Research Project Grant No.: DST/INT/SL/P-14/2016/C\&G which forms a part of this research study. The authors of this research work are extremely grateful to Prof. P. Arulmozhivarman, DeanSchool of Electrical Engineering (SELECT), VIT University and Prof. Sarat Kumar Sahoo, Head- Electrical Engineering, School of Electrical Engineering (SELECT), VIT University for the unstinted support and motivation during the research study.

\section{References}

[1] V. Cooray, "An introduction to lightning," Springer, (2015).https://doi.org/10.1007/978-94-017-8938-7.

[2] V. Cooray, "The lightning flash," IET, $2^{\text {nd }}$ Edition, (2014).https://doi.org/10.1049/PBPO069E.

[3] Uman, Martin A, Andrews, Christopher Joh, Mary Ann Cooper, Mat Darveniza, and David Mackerras, "Lightning injuries: electrical, medical, and legal aspects," CRC Press, 1991.

[4] Drabkin, M. M., C. Y. A. Mui, and Ong Lai Mun, "Lightning protection of tall structures," Int. Conf. Light. Prot. (ICLP), 2012, pp. $1-6$.

[5] Mazur, Vladislav, and Lothar H. Ruhnke. "Sustainable upward leaders from tall structures: Their development and effects," Int. Conf. Light. Prot. (ICLP), 2012, pp. 120.https://doi.org/10.1109/ICLP.2012.6344281.

[6] Hartono, Z. A., and I. Robiah, "Lightning protection for the Holy Mosque and the Jamarat Bridge in Makkah," Int. Conf. Light. Prot. (ICLP)

2014

pp.

$1282-$ 1286.https://doi.org/10.1109/ICLP.2014.6973327.

[7] Reshu Manglik, "This Indian monument has survived a massive earthquake and struck by lightning twice! Can you guess its name?" July 2017. [Online] Available: http://www.indiatvnews.com/lifestyle/news-qutub-minar-amazingfact-survived-earthquake-and-struck-by-lightning-twice-389005

[8] Steve Wilson, Rio de Janeiro's Christ the Redeemer struck by lightning, Jan. 2014. [Online]. Available: http://www.telegraph.co.uk/news/worldnews/southamerica/brazil/1 0581241/Rio-de-Janeiros-Christ-the-Redeemer-struck-bylightning.html

[9] Traffic chaos after lightning strike damages church tower, July $2016 . \quad$ [Online]. Available: http://www.falkirkherald.co.uk/news/traffic-chaos-after-lightningstrike-damages-church-tower-1-4182307

[10] Dennis Romboy, Lightning damages Angel Moroni statue atop Bountiful Temple, May 2016. [Online]. Available https://www.deseretnews.com/article/865654826/Lightningdamages-Angel-Moroni-statue-atop-Bountiful-Temple.html

[11] Wood, Michael, "The story of India, " Random House, (2015)

[12] HISTORIA, [Online]. Available: http://www.thecolosseum.net/history/h1.htm

[13] Zipse, Donald W, "Lightning protection systems: Advantages and disadvantages," IEEE Trans. Ind. App. , Vol. 30, no. 5, 1994, pp. 1351-1361.https://doi.org/10.1109/28.315250.

[14] Rakov, Vladimir A., and Martin A. Uman, "Some properties of negative cloud-to-ground lightning flashes versus stroke order," $J$ Geophys. Res.: Atmospheres, Vol. 95, no. D5, 1990, pp. 5447 5453.https://doi.org/10.1029/JD095iD05p05447.

[15] Füllekrug, Martin, Eugene A. Mareev, and Michael J. Rycroft, eds. "Sprites, elves and intense lightning discharges," Vol. 225, (Springer Science \& Business Media, 2006).https://doi.org/10.1007/14020-4629-4.

[16] V. Cooray, Lightning Electromagnetics, IET, (2012).

[17] Gayen, Arun, Anirban Dhar, B. N. Das, and D. R. Poddar, "A simplified approach to understanding of the phenomenon of cloud to ground lightning and modeling of return stroke current," Proc. Int. Conf. ElectroMag. Inter. Compat. (INCEMIC), 2006, pp. 358-362.
Gomes, Chandima, and Vernon Cooray, "Concepts of lightning return stroke models," IEEE Trans. Electromag. Compat., Vol. 42, no. 1, 2000, pp. 82-96.https://doi.org/10.1109/15.831708.

Lin, Yung-Tao, M. A. Uman, and R. B. Standler, "Lightning return stroke models, Journal of Geophysical Research: Oceans, Vol.85, no. C3, 1980, pp. 15711583.https://doi.org/10.1029/JC085iC03p01571.

Rakov, Vladimir A., and Martin A. Uman., "Review and evaluation of lightning return stroke models including some aspects of their application." IEEE trans. Electromag. Compat., Vol. 40, no. 4, 1998, pp. 403-426.

Liang, C., B. Carlson, N. Lehtinen, M. Cohen, R. A. Marshall, and U. Inan, "Differing current and optical return stroke speeds in lightning," Geophysical Research Letters, Vol. 41, no. 7, 2014, pp. 2561-2567.https://doi.org/10.1002/2014GL059703.

Baba, Yoshihiro, and Masaru Ishii, "Characteristics of electromagnetic return-stroke models," IEEE trans. Electromag. Compat., Vol. 45, no. 1, 2003, pp. 129-134.

Baba, Yoshihiro, and Vladimir A. Rakov, "On the use of lumped sources in lightning return stroke models," J. Geophys. Res.: Atmospheres, Vol. 110, no. 2005.https://doi.org/10.1029/2004JD005202.

Cooray, Vernon, "On the concepts used in return stroke models applied in engineering practice," IEEE trans. Electromag. Compat., Vol. 45, no. 1, 2003, pp. 101-108.

Thottappillil, Rajeev, and Martin A. Uman, "Comparison of lightning return-stroke models,"J. Geophys. Res.: Atmospheres, Vol. 98, no. D12, 1993, pp. 2290322914.https://doi.org/10.1029/93JD02185.

Cooray Vernon, "Lightning Protection," IET, (2010).

Bouquegneau, Christian, "History of lightning," Asia-Pacific Int. Conf. Light. (APL), 2011, pp. 567570.https://doi.org/10.1109/APL.2011.6110191.

Uman, M. A., and V. A. Rakov, "A critical review of nonconventional approaches to lightning protection," Bulletin of the American Meteorological Society, Vol.83, no. 12, 2002, pp. 18091820.https://doi.org/10.1175/BAMS-83-12-1809.

M. Bernardi, C. Bouquegneau, V. Cooray et al, "Lightning Interception - Non Conventional Lightning Protection Systems," CIGRE, WG C4.405 Report, Electra N $N^{0} 258$, Oct. 2011

Hartono, Z. A., and I. Robiah, "Close proximity bypasses to collection volume and early streamer emission air terminals," AsiaPacific Int. Conf. Light. (APL), 2011, pp. 863867.https://doi.org/10.1109/APL.2011.6110249.

Gopuram- The Temple Entrance, August 2012. [Online]. Available: http://theancientindia.blogspot.in/2012/08/gopuram-templeentrance.html

Jegatheesan. Soundarapandian, Kalasam a Great Protector and Redevelopment Source. [Online]. Available: http://www.instructables.com/id/Kalasam-a-great-protector-andredevelopment-source/

R. Sairam, Lightning Conductors being installed at Meenakshi temple, November 2011. [Online]. Available: http://www.thehindu.com/news/national/tamil-nadu/lightningconductors-being-installed-at-meenakshi-temple/article2627820.ece $\mathrm{Hu}$, Jun, and $\mathrm{Chen} \mathrm{Li}$, "Lightning protection of Chinese ancient architecture," Asia-Pacific Int. Conf. Light. (APL), 2011, pp. 844-847. Boyd, Andrew, "Chinese architecture," Alec Tiranti, London, 1962. Gomes, Chandima, Mohd Zainal Abidin Ab Kadir, Mehdi Izadi, and Ashen Gomes, "Lightning current and voltage distribution of large axially symmetric buddhist stupa in Sri Lanka," Int. Conf. Light. Prot. (ICLP), 2014, pp. 1637-1651.

Al-Qayrawan Mosque. [Online]. Available: http://www.muslimheritage.com/article/al-qayrawan-mosque TURNS, B. F., "Benjamin Franklin and lightning rods," Physics Today, Vol. 59, no. 1, 2006.

Rakov, Vladimir A., and Martin A. Uman., "Lightning: physics and effects," Cambridge University Press, (2003).https://doi.org/10.1017/CBO9781107340886.

Tobias, John M, "The basis of conventional lightning protection systems," IEEE Trans. Indus. App., Vol. 40, no. 4, 2004, pp. 958962.https://doi.org/10.1109/TIA.2004.831277.

Cohen, I. Bernard, "Prejudice against the introduction of lightning rods," J. Franklin Institute, Vol. 253, no. 5, 1952, pp. 393440.https://doi.org/10.1016/0016-0032(52)90718-7.

Rakov, Vladimir A, "Lightning discharge and fundamentals of lightning protection," J. Light. Res., Vol. 4, no. 1, 2012, pp. 311.https://doi.org/10.2174/1652803401204010003.

National Fire Protection Association, "NFPA 780: Standard for the Installation of Lightning Protection Systems," (2017). 
[44] IEC 62305, "Protection against lightning, composed of four parts: IEC 62305-1 to 4," 2006

[45] IEEE 998, "IEEE Guide for Direct Lightning Stroke Shielding of Substations," IEEE, 2012.

[46] BIS IS 2309:1989, "Code of Practice for the Protection of Buildings and Allied Structures Against Lightning," Bureau of Indian Standard (BIS), 2010.

[47] Horvath, Tibor, "Problems and solution of utilizing the protection angle method," Int. Conf. Light. Prot. (ICLP), 2010, pp. 1-7.

[48] ZHANG, Zhi-jin, Wen-xia SIMA, Xing-liang JIANG, Cai-xin SUN, and Li-chun SHU, "Study on The Lightning Protection Performance of Shielding Failure for UHV\&EHV Transmission Lines," Proc. Chinese Society Electrical Engineering, Vol. 10, 2005 .

[49] Lee, Ralph H, "Protection Zone for Buildings Against Lightning Strokes Using Transmission Line Protection Practice," IEEE transactions on industry applications, Vol. 6, 1978, pp. 465469.https://doi.org/10.1109/TIA.1978.4503576.

[50] Nassereddine, Mohamad, and Ali Hellany, "Designing a lightning protection system using the rolling sphere method," Int. Conf. Comp. Elec. Eng. (ICCEE'09), vol. 1, 2009, pp. 502-506.

[51] Brusso, Barry, "The Electrogeometrical Model of the Rolling Sphere Method [History]," IEEE Indus. App. Magazine, Vol. 22, no. 2, 2016, pp. 7-70.https://doi.org/10.1109/MIAS.2015.2503940.

[52] Xie, Qizhang, Stephane Baron, Simon Fortin, and Farid P. Dawalibi, "Rolling sphere method using 3D Graphics approach," Asia-Pacific Power and Energy Engineering Conference (APPEEC 2009), 2009, pp. 1-4.

[53] Cooray, Vernon, Vladimir Rakov, and Nelson Theethayi. "The lightning striking distance-Revisited.” J. Electrostat. , Vol. 65, no. 5, 2007, pp. 296-306.https://doi.org/10.1016/j.elstat.2006.09.008.

[54] Ait-Amar, Sonia, and Gérard Berger, "A modified version of the rolling sphere method," IEEE Trans. Dielec. Elec. Insul., Vol. 16, no. $3, \quad 2009$, pp. 718 725.https://doi.org/10.1109/TDEI.2009.5128511.

[55] Horvath, Tibor, "Standardization of lightning protection based on the physics or on the tradition?" J. Electrostat., Vol. 60, no. 2, 2004, pp. 265-275.

[56] Cooray, V., and L. Arevalo, "The mesh method in lightning protection analyzed from a lightning attachment model," Int. Conf. Light.
Prot.
(ICLP),
2016 ,
pp.

5.https://doi.org/10.1109/ICLP.2016.7791431.

[57] Arevalo, Liliana, and Vernon Cooray, "The mesh method 'in lightning protection standards-Revisited," J. Electrostat., Vol. 68, no. 4, 2010, pp. 311-314.https://doi.org/10.1016/i.elstat.2010.03.003.

[58] Wagner, C. F., G. D. McCann, and C. M. Lear, "Shielding of substations, Electrical Engineering," Vol. 61, no. 2, Feb. 1942, pp. 9699.https://doi.org/10.1109/EE.1942.6436188.

[59] H. Linck, "Shielding of modern substations against direct lightning strokes," IEEE Trans. Power Apparatus and Systems, Vol. 94, no. 5, Sept. 1975, pp. 1674 - 1679.https://doi.org/10.1109/TPAS.1975.32010.

[60] Horvath, Tibor, "Understanding lightning and lightning protection: a multimedia teaching guide," John Wiley \& Sons, (2006).

[61] Vale, Thomas, ed., "Fire, native peoples, and the natural landscape," Island Press, (2013).

[62] Smith, Thomas J., Michael B. Robblee, Harold R. Wanless, and Thomas W. Doyle, "Mangroves, hurricanes, and lightning strikes," BioScience, Vol. 44, no. 4, 1994, pp. 256262.https://doi.org/10.2307/1312230.

[63] Whelan K. R. J., T. J. Smith III and I. Van Leth, "Lightning Gap Characteristics in Mangroves of South Florida," The Ecological Society of America 87 ${ }^{\text {th }}$ Annual meeting - Tucson, Arizona, 2002.

[64] Zhang, Keqi, "Identification of gaps in mangrove forests with airborne LIDAR," Remote Sensing of Environment, Vol. 112, no. 5, 2008, pp. 2309-2325.https://doi.org/10.1016/j.rse.2007.10.003.

[65] Whelan, Kevin Richard Terrence, "The successional dynamics of lightning-initiated canopy gaps in the mangrove forests of Shark River, " Everglades National Park, USA, Ph.D Diss., Florida International University, 2005.

[66] Kevin R. T. Whelan and Thomas J. Smith, "Characteristics of Lightning Gaps in the Mangrove Forests of Everglades National Park," Greater Everglades Ecological Research (GEER) Science Conference, Naples, Florida, Oct. 2003.

[67] Whelan, K. R. T. and T. J. Smith III, "Root Mortality in Recent Lightning Formed Canopy Gaps of a Neotropical Mangrove Forest Leads to Soil Elevation loss," The Association of Tropical Biology, Miami, Florida, 2004. 